\title{
Family Limited Partnerships Under Attack: Is the End Near?
}

Debra M. Grace, (E-mail: dgrace@ csulb.edu), California State University, Long Beach Michael D. Chase, (E-mail: mdchase@csulb.edu), California State University, Long Beach

\begin{abstract}
Family Limited Partnerships (FLPS) represent unique vehicles for transferring wealth, such as family businesses, from one generation to another, permitting parents to gradually transfer business ownership to children while maintaining control over operations. FLPs also serve as significant shields against the effects of gift and estate taxes, since valuation discounts can be employed to reduce the fair market value of partnership interests transferred to children and other family members. However, these tax savings have resulted in aggressive audit and court challenges by the IRS. For accountants, responding to these challenges for their clients means understanding both how the financial and tax aspects of FLPs operate. This article details the critical nontax aspects of FLPs and presents a thorough examination of current tax developments, including the June 2002 appellate court decisions. Finally, the article discusses specific steps accountants should take in advising their clients to protect family assets and defend against IRS attacks.
\end{abstract}

\section{Introduction}

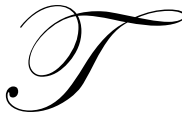

ransferring family wealth from one generation to another, particularly when it exists in the form of a family business can be a difficult and complex process. Parents may not wish to cede immediate control over the business to children and no one involved wants to see the assets' value diminished by the onerous burden of gift and estate taxes. By employing Family Limited Partnerships (FLPs) to transfer family wealth, parents can accomplish the twin goals of maintaining parental control over the assets while greatly minimizing the impact of transfer taxes through use of valuation discounts.

However, because of their success in reducing transfer taxes, FLPs have come under increasingly heavy attack by the IRS. In numerous court cases and pronouncements, the Service has challenged the validity of FLPs, asserting the entities are shams formed only to escape the effects of gift and estate taxes. While the IRS has lost several recent cases, it has also managed to rack up a few wins. Moreover, the Service has been quick to appeal its losses.

Recent Congressional actions may doom FLPs for entirely different reasons. In April 2002, the U.S. House of Representatives passed a bill to permanently eliminate the estate tax. ${ }^{1}$ Currently, estate tax rates will phase down to zero by 2010 , then reemerge at $55 \%$ for 2011 and subsequent years. ${ }^{2}$ Although the bill did not pass the Senate, ${ }^{3}$ it seems likely that the upcoming fiscal year will see more attempts to repeal the estate tax.

Eliminating the estate tax removes a major tax benefit of FLPs--the valuation discount. This discount, usually employed to reflect considerations such as limited marketability or lack of liquidity of FLP interests, lets a substantial portion of the assets' transferred to the FLP escape estate taxation. If the estate tax is eliminated, the value of such discounts is nil. Even though the gift tax would remain (neither the 2001 or 2002 tax bills eliminated

Readers with comments or questions are encouraged to contact the authors via email. 
it), taxpayers might have little tax incentive to make lifetime transfers of family businesses to their children using FLPs, when the result could be achieved tax-free at death.

In these volatile times, should taxpayers use FLPs to shift family assets to offspring or other family members? To assist taxpayers, this article details the critical aspects of FLPs, offering first a brief overview of the nontax consideration of forming a FLP. Secondly, the article examines the current tax developments affecting FLPs, including recent appellate court decisions. Finally, advice is offered on how best to structure the FLP to present a strong defense against IRS challenges.

\section{Non-Tax Aspects of the FLP}

What Assets Lend Themselves to FLPs?

In a FLP, all, or substantially all, of the limited partners are family members. The limited partnership must be validly formed under state law and must have at least two partners: a general partner and a limited partner. A partner can be an individual, trust or a corporation.

FLPs can serve as vehicles for transferring family wealth from parents to children, while permitting parents to retain control over the wealth. For example, transferring commercial real estate to the FLP lets parents with a general partnership interest maintain operational control of the realty, but enables them to move assets when needed out of the FLP to children holding limited partnership interests. This, in turn, protects the transferred assets from creditors of the general partners (parents).

Other examples of assets appropriate for transfer to FLPs would be family businesses or rental real estate. Generally, transferring business-related assets provides greater defense against IRS scrutiny, since the Service uses lack of business purpose as one means of attack. However, as discussed later in this article, the IRS' business purpose challenge has proved ineffective in recent court decisions.

Types of Estate Assets that should be avoided by FLP's

While FLPs can be funded with other partnership interests, they should not hold S corporation stock, because this terminates $\mathrm{S}$ corporations status. However, at least two proposals in recent years would permit FLPs to be S corporation shareholders where all partners were members of one family, as determined by Sec. 704(e)(3). ${ }^{4}$ In general, assets lacking business purposes should not be used to fund FLP's. Caution is indicated on the transfer of personal assets to the FLP, such a family home. While the transfer would protect the home against claims against the general partner, it exposes the home to creditor claims against the partnership. It may also void the transfer for estate tax purposes under Sec. 2036 if the transferor continues to use the residence, as was the case in Reichardt ${ }^{5}$ and Schauerhamer, ${ }^{6}$ both of which are discussed in later sections of this article.

\section{Benefits of a FLP}

\section{Defined Control and Risk for General and Limited Partners}

While holding a general partnership interest in an FLP permits control of day to day operations of the partnership (including the timing of distributions to the limited partners), it also exposes the general partner to unlimited liability for partnership debts. This can be resolved by using a corporation or a Limited Liability Company (LLC) as the general partner. In contrast, limited partners have no role in the partnership operations and have their risk limited to the cost basis of their partnership interests.

\section{Advantages over an Irrevocable Living Trust}

Because partners can transfer their interests (to the extent permitted by the partnership agreement), a FLP offers more flexibility than an irrevocable trust-permitting the addition of more family members as limited partners 
in the future. At death, only the decedent's own partnership interest (whether general or limited) is included in the estate. No interest in the FLP given by the decedent to other family members is included in the estate, even though the decedent as the general partner had control over partnership assets. This ability to retain control over assets in the estate is a major advantage of an FLP over an irrevocable trust. In the latter, the transferor's retention of the right to control distributions to other beneficiaries will cause trust assets to be included in the donor's estate, under Sec. 2036.

However, taxpayers forming FLPs must be aware that the IRS has been successful in employing Sec. 2036 in FLP situations. Sec. 2036 "pulls back" into the decedent's estate any previously transferred property where the decedent retained incidents of ownership or enjoyment (or had the ability to designate these rights to others). Where taxpayers have carelessly disregarded the FLP's existence by living in FLP-owned residences without paying rent, or commingling business and personal funds, or having the FLP pay personal expenses, the Service has won in court on the Sec. 2036 issue. This situation is discussed in more detail later in this paper.

\section{Protection From Creditors}

Since the partnership is owned by all of the partners, it is more difficult for creditors of individual partners to attach the business' jointly-owned assets. Parents acting as general partners can further protect assets against creditors by limiting their ownership interests to as little as $1 \%$ or by forming a corporation to act as the general partner while they take a limited partner position.

Creditors of a specific partner may be able to obtain charging orders giving them the right to receive distributions of the debtor partner. However, since the general partner controls FLP distributions, the viability of a charging order for a FLP may be nil. Moreover, the charging order makes the creditor liable for a pro-rata share of partnership taxable income, even though no distributions are made. This protection only blocks claims against the partnership for non-partnership activities of a specific partner. No such protection is offered for the activities of the partnership itself.

Further, creditors may have specific remedies under state law other than charging orders which give them access to partnership assets. Courts will examine FLPs closely in cases where the entities are effective in blocking creditors and will closely examine whether a valid business purpose exists for the FLP. FLPs deemed to be formed primarily for the protection of assets are commonly viewed by the courts as a device to defraud creditors and may be voidable.

\section{Allocation of Income Between Family Members}

Because FLP income is allocated according to the partnership agreement, taxable income can be shifted from higher income parents/partners to lower income children/partners. This may also serve to convert passive income into earned income if the child provides services to the partnership and may permit the creation of a qualified retirement plan resulting in further shielding of the income from taxation. It is critical that allocations of taxable income gains, losses, and deductions be consistent with the reality of the services provided by the partners. In businesses such as real estate, where capital is a significant income producing factor, parents will need to plan on giving limited partnership interests to their children to permit allocations of income to follow.

\section{Transfer Considerations}

\section{Depreciation}

The transfer of depreciable property to the FLP spreads the depreciation adjustment proportionately to all partners. This can be problematic in the case of children who are limited partners and lack income or are in lower tax brackets than the general partners. 


\section{Disguised Sales}

In most situations, assets can be contributed to a partnership without tax consequences unless the disguisedsale rules come into consideration. Creating a gain under the disguised-sale rules can normally be avoided by not permitting any distributions of the contributed property for a reasonable time period subsequent to the formation of the FLP.

\section{Debt Burdened Property}

Finally, contributions of property with debt greater than basis will result in taxable gain to the donor unless the donor remains liable for the debt subsequent to the contribution.

\section{Illustrative Examples of Common Uses of FLP's}

When might using an FLP make sense? The following examples are situations often encountered by practitioners when an FLP could be a solution to tax, inheritance and liability protection concerns.

\section{Example 1}

John and Joan Jones have three teenage children and own $\$ 1$ million of valuable income-producing real estate. They would like to start making annual gifts of $\$ 11,000$ each to take advantage of the gift tax exclusion and to provide college funding for the children. They do not want to establish trusts because of the high tax rates on retained trust income. They have also rejected the idea of custodial accounts, since the children could gain unsupervised access to funds at age 18 .

By transferring the real estate to an FLP, John and Joan can begin shifting family assets to their children while maintaining operational control over. Each year, the parents could transfer $\$ 24,444$ of limited partnership interests to each child tax free (employing a $10 \%$ minority interest discount of $\$ 7,333$ and $\$ 66,000$ of gift tax exclusions), for a total of $\$ 73,333$. $^{7}$ As general partners, John and Joan can control distributions to the children even after age 18. The partnership property cannot be sold unless the parents choose to do so.

\section{Example 2}

Thomas Brown is a recently widowed senior citizen with three adult children and a wholly owned business worth about $\$ 1$ million. The business is expected to continue to grow rapidly. His wife's death has forced Thomas to face his immediate estate planning needs. If the business increases in value to $\$ 2$ million, the federal estate tax due on his death will be $\$ 500,000$ in 2002 . Consequently, he would like to remove the business from his taxable estate without giving up control over its operations.

Thomas contributes the business to an FLP designating an S Corporation owned by him as the $1 \%$ general partner. Thomas will continue to be employed by the business so his salary needs will provide his income. Initially, Thomas holds $96 \%$ of the limited partnership interest. Each of his children makes a contribution to the partnership and holds an initial $1 \%$ limited partnership interest. Thomas then divides his $96 \%$ limited partnership interest worth $\$ 1$ million into three equal pieces and gives them to his three children. Qualified appraisers determine a 20\% minority discount along with a $20 \%$ lack of marketability discount as an appropriate reduced value for the interests.

Consequently, Thomas is able to reduce the value of his estate by $\$ 1$ million, as the taxable basis of the gifts is only $\$ 640,000$. $^{8}$ Furthermore, $\$ 33,000$ of the $\$ 640,000$ will be exempt from gift taxes due to the yearly exclusion; the remainder can be excluded by using a portion of his $\$ 1,000,000$ unified tax credit equivalent, thus eliminating any gift tax bill. 


\section{Tax Aspects of the FLP}

\section{The IRS' Position}

The IRS views FLPs as devices formed to escape transfer taxes. This view is triggered by taxpayers' aggressive uses of valuation discounts (some up to 50-55\%) when transferring limited partnership interests to family members as gifts or devises. For example, in Strangi, ${ }^{9}$ using a FLP as a transferring vehicle reduced the amount subject to estate taxes from $\$ 9.9$ million to $\$ 6.6$ million. Similarly, in Knight, ${ }^{10}$ assets worth $\$ 2.2$ million were valued at $\$ 1$ million after use of a FLP and valuation discounts.

\section{A Typical Example}

Illustration One indicates how a typical FLP transaction is structured. The taxpayer forms both a FLP and usually a second entity, such as a corporation, to serve as the FLP's general partner. In this example, a $\$ 5$ million transfer of assets from the taxpayer funds the corporate general partner for $\$ 50,000$ and secures a $99 \%$ limited partner's interest in the FLP worth $\$ 4.95$ million (Step One of Illustration One).

In Step Two, the taxpayer transfers all or a substantial portion of the limited partnership interest to other family members--in this case, to three children. Because what the taxpayer conveys at this point is not clear title and ownership of the actual assets, but only ownership of limited partnership interests, a valuation discount (or discounts) is/are applied to reflect the reduced control over the partnership assets that the children hold as minority limited partners. It is this reduced valuation ( $\$ 3.465$ million in Illustration One) that serves as the tax basis for the transfer taxes (reduced in the case of gifts by the yearly $\$ 11,000$ per donee exclusion and by any application of the unified transfer tax credit).

An obvious question to ask is why the diminution of value from $\$ 4.95$ to $\$ 3.465$ million does not occur on the taxpayer's initial transfer of assets into the FLP in exchange for the $99 \%$ limited partnership interest. The IRS has advanced this position in court (albeit unsuccessfully), arguing the taxpayer has made a gift on formation of the FLP equal to this drop in value. As explained in the following pages, this argument has, with rare exception, fallen on deaf ears in the courts.

\section{The Strangi Case}

Illustration Two shows the elements in the Tax Court case of Strangi. ${ }^{11}$ The taxpayer's son-in-law, acting under power of attorney, formed a FLP and a corporation. Strangi contributed $\$ 9.9$ million in assets (75\% of which was cash and receivables) to the FLP for a $99 \%$ limited partnership interest and $\$ 49,350$ to the corporation for a $47 \%$ interest. His children contributed $\$ 55,650$ to the corporation for a 53\% interest. The corporation then contributed its $\$ 105,000$ to the FLP for a $1 \%$ general partnership interest.

When Strangi died, his estate distributed the 99\% limited partnership interest proportionately to the four children. The children contributed a combined $1 \%$ of their interests in the FLP to a local college. A fair market value (FMV of $\$ 6.6$ million for the limited partnership interests was recorded for estate tax purposes.

\section{The Knight Case}

Illustration Three shows the elements in the Tax Court case of Knight. Here taxpayers (husband and wife) formed a FLP and a managing trust to serve as the FLP's general partner, contributing \$2 million in assets to the FLP for a 100\% limited partnership interest and then contributing $1 \%$ of that interest to the managing trust. Taxpayers served as trustees for the managing trust.

Taxpayers then gifted $89.2 \%$ of their FLP limited partnership interest to two trusts established for their children. The children were the trustees and beneficiaries of the trusts. The FMV recorded for the gift was $\$ 1$ million after valuation discounts. 


\section{The IRS' Arguments Against FLPs}

Eager to curb what it feels is a growing abuse of the use of FLPs and their related cousins, family limited liability companies (FLLCs), the IRS has stepped up audits and is aggressively attacking FLPs and FLLCs in court. The IRS' National Office has issued instructions to its agents for opposing FLPs in Field Service Advice (FSA) $200049003^{12}$ and FSA 200143004. ${ }^{13}$ The grounds for attack listed in the FSAs and echoed in the government's court arguments, are as follows:

(1) Economic substance doctrine

(2) Sec. 2703

(3) Sec. 2704

(4) Gift on formation

(5) Sec. 2036 (in estate tax situations)

(6) Amount of valuation discount

With the exception of items 5 and 6, each argument above seeks to ignore the FLP, so that the full value of assets transferred by the taxpayer to the entity becomes subject to transfer taxes, instead of the greatly reduced value of the limited partnership interest conveyed by the taxpayer to other family members. This approach has met with little success in litigation. The courts have disagreed, choosing to respect FLPs and FLLCs validly formed under applicable state law. With respect to valuation discounts, even the Field Service Advices grudgingly concede that such discounts may be necessary. ${ }^{14}$ This concession by the Service is offered only "if the taxpayer can show the form of the FLLC must be respected." ${ }^{15}$ Each of these arguments is discussed in the paragraphs that follow.

\section{Recent Developments}

The Fifth Circuit Court of Appeals has just handed down a decision in Strangi, ${ }^{16}$ agreeing with the Tax Court that the FLP should be respected and affirming the lower court's decisions for the taxpayer on the issues of business purpose and economic substance, Sec. 2703, gift on formation and valuation discounts. The appeals court remanded Strangi back to the Tax Court to reconsider a Sec. 2036 issue not addressed by the trial court. The Sec. 2036 issue is discussed later in this article.

In addition, the Fifth Circuit also affirmed for the taxpayer in Kerr, ${ }^{17}$ again upholding recognition of the FLP as an entity and permitting the valuation discounts. In Kerr, the issue was the Service's attempt to apply Sec. 2704 to ignore the FLP. Sec. 2704 and the Kerr case are also discussed in subsequent pages. 


\section{Illustration One}

Step One: Formation of FLP and Corporation:

(a): Taxpayer (TP) forms a Corporation (CORP), contributing $\$ 50,000$ for $100 \%$ ownership. The transfer is nontaxable under Sec. 351 .

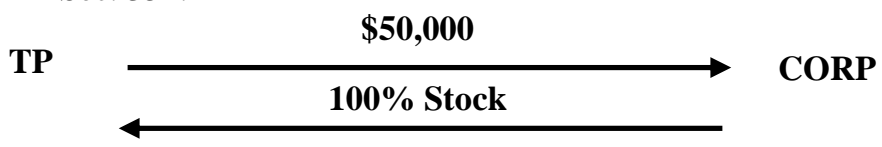

(b): TP forms a Family Limited Partnership (FLP), contributing $\$ 4,950,000$ for a $99 \%$ limited partnership interest (LP interest). The transfer is nontaxable under Sec. 721.

TP

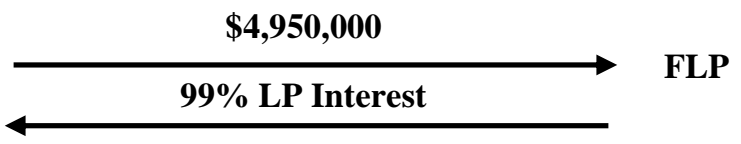

(c): CORP contributes $\$ 50,000$ to FLP for a $1 \%$ general partnership interest (GP Interest). The transfer is nontaxable under Sec. 721.

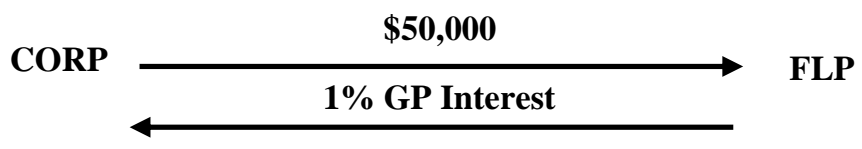

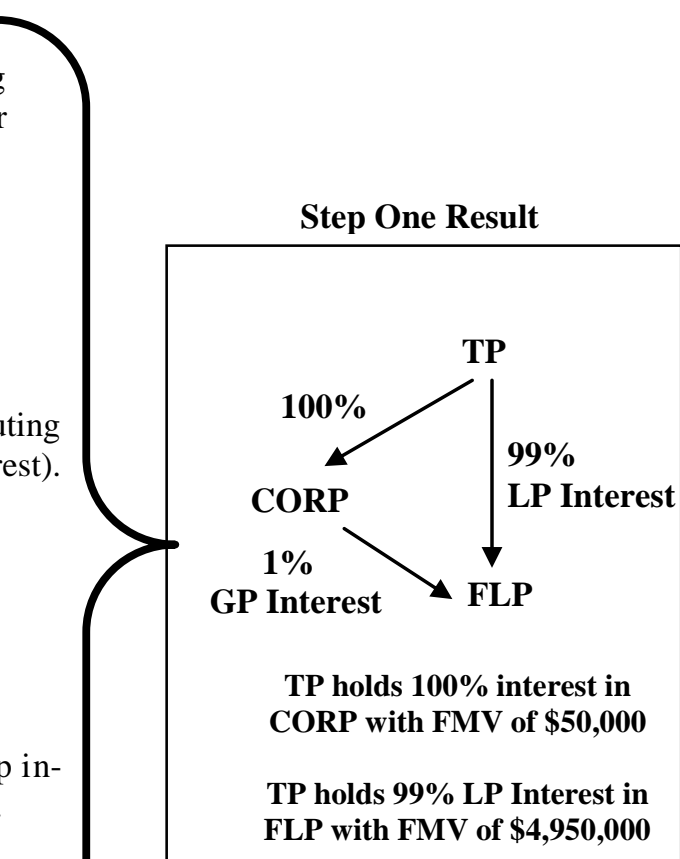

Step 2: Distribution of Limited Partnership Interest to Taxpayer's Children and Application of Valuation Discount

Taxpayer gives a 33\% LP interest to each of TP's three children (C1, $\mathrm{C} 2$ and $\mathrm{C} 3$ ). A 30\% minority discount is applied, resulting in a FMV for gift tax purposes of $\$ 3,465,000$ for the total interests transferred (before consideration of the $\$ 11,000$ yearly exclusions and the unified credit).
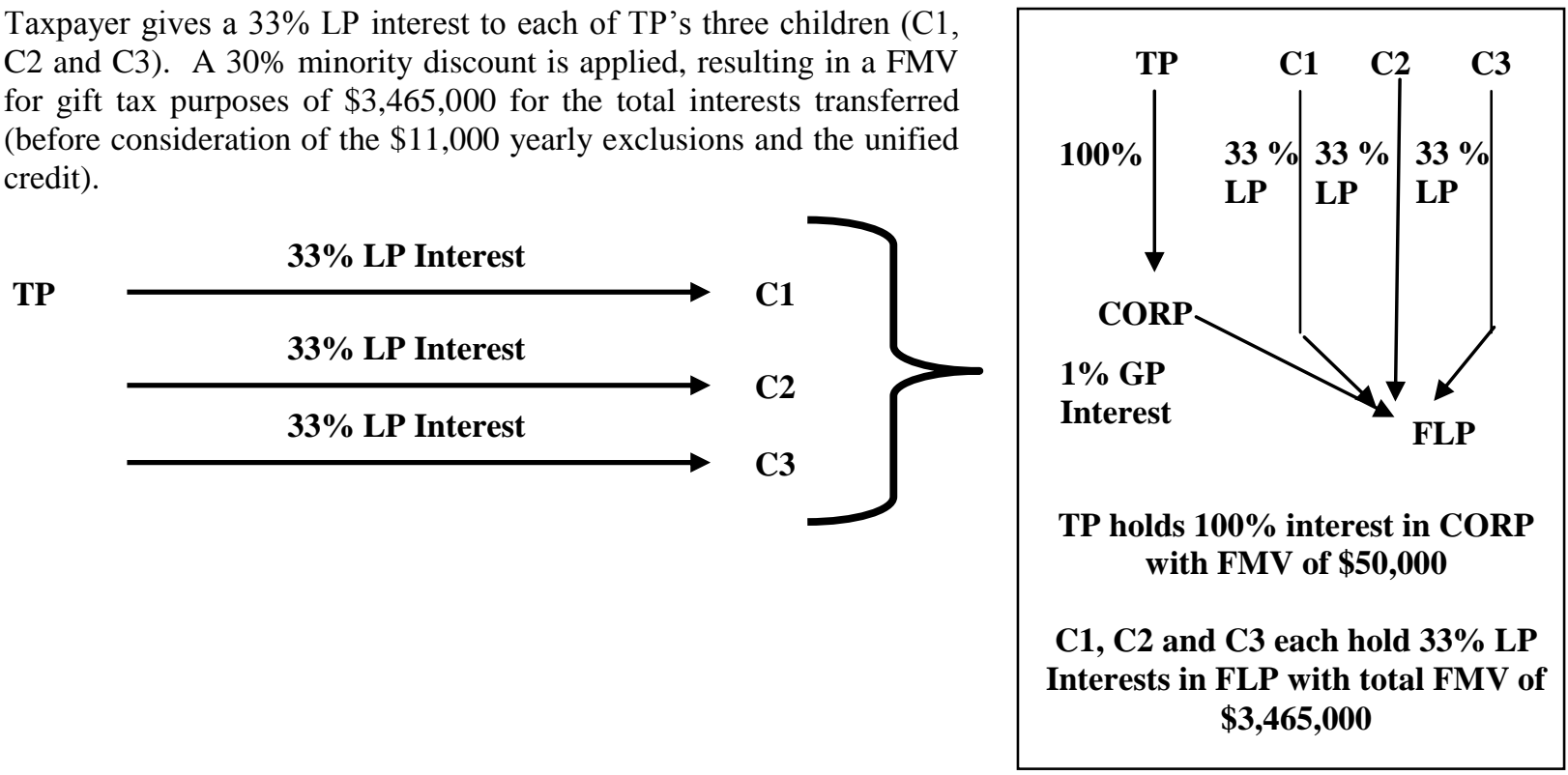


\section{Illustration Two - The Strangi Case}

Step One: Formation of FLP and Corporation:

(a): Taxpayer (TP) forms a Corporation (CORP), contributing $\$ 49,350$ for $47 \%$ ownership. TP's children (TPC) contribute $\$ 55,650$ for $53 \%$ ownership.

\section{ribute}

\$ 55,650 for $53 \%$ ownership.

$\mathbf{T P}$

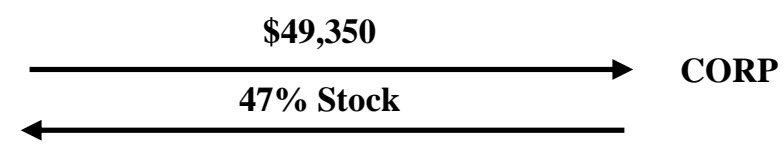

TPC

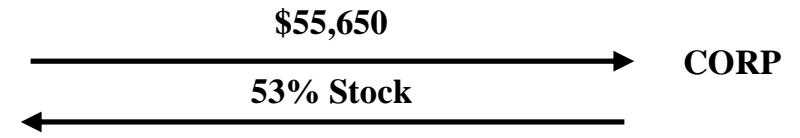

(b): TP forms a Family Limited Partnership (FLP), contributing $\$ 9.9$ million for a $99 \%$ limited partnership interest (LP interest). CORP contributes $\$ 105,000$ for a $1 \%$ general partner's interest

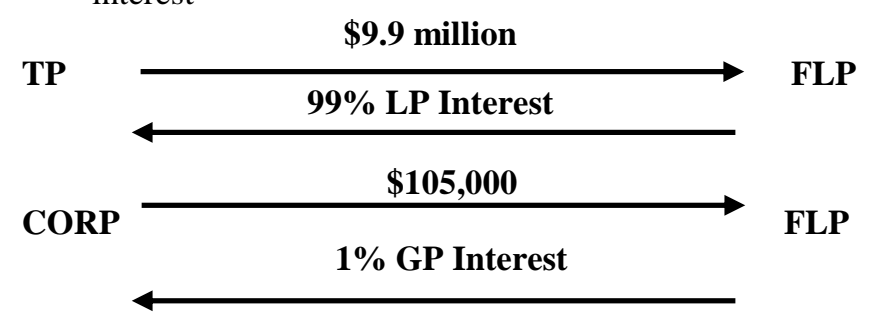

Step One Result

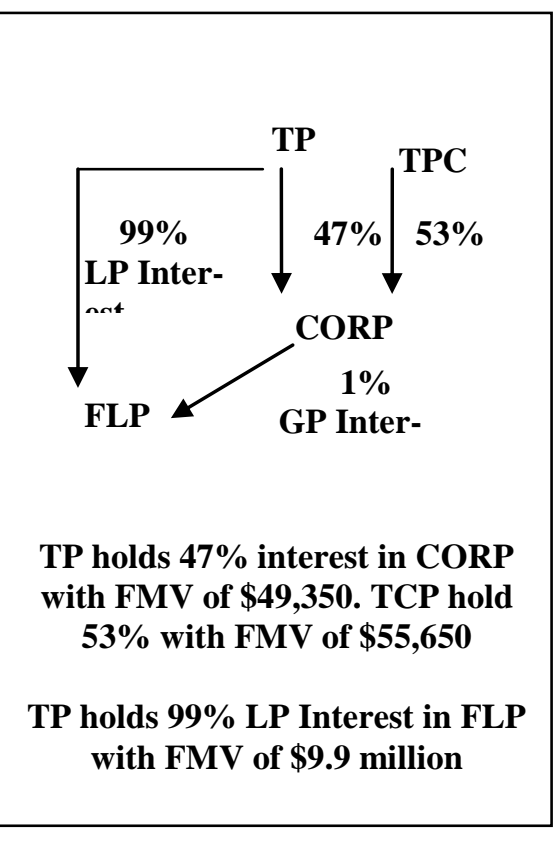

Step 2: Distribution of Limited Partnership Interest to Taxpayer's Children and Application of Valuation Discount

Taxpayer's estate (ESTATE) gives 99\% LP interest to TP's children (TPC). A $25 \%$ minority discount and a $25 \%$ marketability discount are applied, resulting in a FMV for estate tax purposes of $\$ 6.6$ million. TPC then transferred $1 \%$ of their interests to a college (SCHOOL).

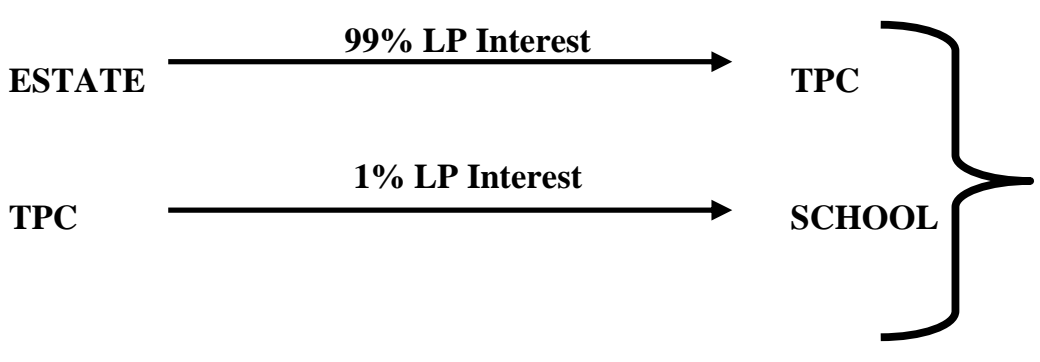

TPC holds $98 \%$ LP Interest in FLP with FMV of $\$ 6.65$ million 
Step One: Formation of FLP and Managing Trust:

(a): Taxpayer (TP) forms a Family Limited Partnership (FLP), contributing $\$ 2.08$ million for a $100 \%$ limited partnership interest (LP interest). The transfer is nontaxable under Sec. 721.

TP

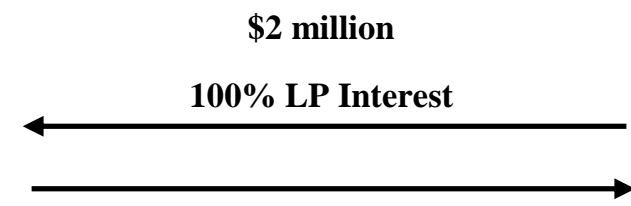

(b): TP forms a Managing Trust (MT), contributing a $1 \%$ interest in the FLP. The trust serves as general partner in the FLP.

\section{$1 \%$ LP Interest}

TP

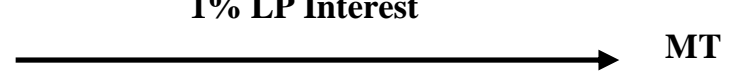

STEP ONE RESULT

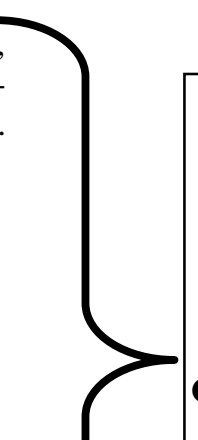

Step 2: Distribution of Limited Partnership Interest to Children's Trusts and Application of Valuation Discount

STEP TWO RESULT

TP gives $89.2 \%$ LP interests to children's trusts (CT). Valuation discounts are applied, resulting in a FMV for gift tax purposes of $\$ 1.04$ million for the total interests transferred.

89.2\% LP Interest

TP

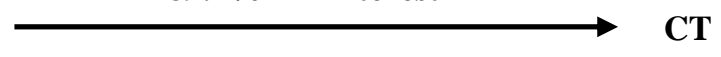

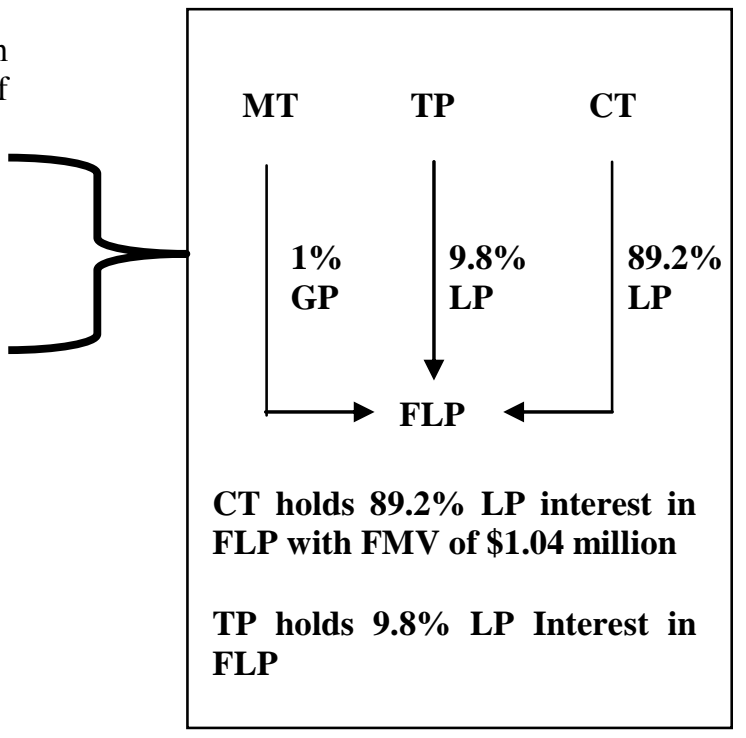




\section{Economic substance doctrine: IRS Argues Income Tax Standard Should Apply in Transfer Tax Cases}

The economic substance doctrine originated in Gregory v. Helvering, ${ }^{18}$ where the Supreme Court held a corporate formation and subsequent reorganization could be disregarded when the substance of those transactions was to avoid tax on a transfer of stock. In FSA 20049003, the Service indicated it will apply the economic substance doctrine to FLPs and FLLCs by questioning the following:

- Whether the taxpayer had a valid business purpose or profit motive for the transaction and

- Whether the transaction appreciably changed the taxpayer's economic position." 19

In cases such as Strangi ${ }^{20}$ and Knight, ${ }^{21}$ the Service argued FLPs should be ignored because they lacked economic substance. This would have required taxpayers to base the transfer taxes on a proportionate share of the fair market value of the actual partnership assets and not on the value of the limited partnership interests transferred, thus eliminating any valuation discounts.

However, in relying on the economic substance doctrine, the IRS is championing a standard most successfully employed in court to challenge abuses involving income taxes; not transfer taxes. The use of the business purpose argument has proved unsuccessful in transfer tax situations. In concurring opinions to Strangi ${ }^{22}$ and Knight $^{23}$ the judges state bluntly "the economic substance doctrine, with its emphasis on business purpose, is not a good fit (when) dealing with donative transfers. ${ }^{24}$ Similarly, "the Court should conclude that the economic substance doctrine does not operate to disregard a validly formed entity where the issue is the value for Federal gift and estate tax purposes of the interest transferred in that entity. ${ }^{25}$

\section{The Tax Court: Business Purpose Not Controlling for Transfer Taxes}

When evaluating the IRS' economic substance arguments, the Tax Court downplays the importance of business purpose. In Strangi, for example, the Court flatly notes "we are skeptical of the estate's claim of business purposes"26 since there were "no business assets contributed" 27 to the FLP. Similarly, in Knight, the facts stipulate that the FLP "never conducted any business activity," 28 and the "partners never met and never discussed any business activity." 29

Instead, the Court's application of the economic substance doctrine rests substantially on the second prong of the argument as to whether the taxpayer's economic position has been appreciably changed by the transaction. In essence, the Court has ruled that, if the taxpayer validly forms a FLP under applicable state law, the Federal government must respect the creation of this entity and the alterations the entity imposes on ownership and control of the underlying assets. As noted in a concurring opinion to Knight, "if taxpayers are willing to burden their property with binding legal restrictions that, in fact, reduce the value of such property, we cannot disregard such restrictions." 30

\section{The Tax Court's Interpretation of the Economic Substance Test}

Since both Strangi ${ }^{31}$ and Knight $^{32}$ represent cases reviewed en banc by the full Tax Court (a relatively rare situation), the importance of the Court's determination that the economic substance test rests not on business purpose, but on the changed economic position of the taxpayer, should not be taken lightly. In essence, this means state law will control when defining property rights for transfer taxes; federal law determines only the appropriate tax treatment of these rights. ${ }^{33}$

The Tax Court interprets the economic substance test doctrine for FLPs along the two dimensions - the first, an objective test; the second, a subjective matter of opinion. The two dimensions are as follows:

- $\quad$ Whether the FLP is validly formed under applicable state law and

- $\quad$ Whether a hypothetical willing buyer would respect the FLP. 


\section{Valid Partnership Formation-The Objective Test}

Creating a FLP means state law defines the relationships between general and limited partners, usually in accordance with the Revised Uniform Limited Partnership Act. Because the partnership agreement imposes legal rights and restrictions on the partners, enforceable in court, the partners' legal control over partnership assets, particularly the limited partners', is fundamentally altered. As the Tax Court indicates in Strangi the FLP "changed the relationships between decedent and his heirs and decedent and actual and potential creditors." ${ }^{34}$ Similarly in Knight, the taxpayers' "rights and legal relationships and those of their children changed significantly when petitioners formed the partnership, transferred assets to it and transferred interests in the partnership to their children's' trusts." 35

Defining the economic substance test solely on the unidimensional question of whether or not a FLP was validly formed seems somewhat simplistic, leading one to question whether the Court is now exalting form over substance. Perhaps to counter this, the Tax Court has linked the valid formation test with a corollary "willing buyer/willing seller" requirement. Thus, mere creation of an entity to hold taxpayer's assets, while an arguably necessary first step in the FLP dance of transfer of ownership, is not sufficient to guarantee the economic substance test is met. The question becomes whether an independent third party, the "hypothetical buyer," would also recognize and respect the changes imposed by state law on the assets.

\section{The Willing Buyer/Willing Seller Subjective Test}

The amount of tax for Federal estate and gift tax purposes is based on the fair market value (FMV) of the property transferred. ${ }^{36}$ This FMV, in turn, is defined as "the price at which such property would change hands between a willing buyer and a willing seller, neither being under any compulsion to buy or to sell, and both having reasonable knowledge of relevant facts." 37

In Knight, the Court applied the "willing buyer/willing seller" standard, indicating they would not disregard the FLP because "we have no reason to conclude from this record that a hypothetical buyer or seller would disregard it." ${ }^{38}$ Further, "the form of the transaction here (the creation of the partnership) would be taken into account by a willing buyer." 39 Likewise, in Strangi, the FLP's existence "would not be disregarded by potential purchasers of decedent's assets. ${ }^{, 40}$

How does a taxpayer ensure compliance with this hypothetical standard? Certainly, a critical element is adherence to the legal formalities of the FLP. The FLP must be validly formed, title to transferred assets should move to the entity, partnership tax returns and Schedule K-1s must be filed. While business purpose may no longer be a controlling factor, the taxpayer and his offspring will strengthen their cases against an economic substance argument by respecting the legal form of the FLP and behaving in businesslike fashion in their dealings with the entity. Thus, if the limited partners enjoy the use of FLP assets such as rental real estate, they should also pay rents equal to FMV for this use; if the general partner authorizes distributions from the FLP to limited partners, it should be based on business reasons and not driven by family relationships between the general and limited partners.

\section{Strangi: The Appeals Court Decision}

In its recent decision in Strangi, the Fifth Circuit Court of Appeals has upheld the Tax Court's decision for the taxpayer in the business purpose/economic substance test. The Court noted that the partnership agreement "changed legal relationships between decedent and his heirs and creditors" ${ }^{1}$ and thus, the FLP must be respected. Further, the appellate court upheld the willing buyer/willing seller standard by emphasizing that "potential purchasers of decedent's assets would not disregard the partnership.",42

As important as the Fifth Circuit's decision is, it does not control court outcomes in other circuits. There, the IRS will continue to apply its collection of arguments against the FLP. The next section of this paper emphasizes that, in respecting the legal form of the FLP, it is critical not to impose restrictions on the FLP beyond those contained in applicable state law. To do so weakens the taxpayers' case that the FLP is a separate legal entity and gives 
credence to the Sec. 2704 argument advanced by the IRS in seeking to ignore the FLP. Sec. 2704 and the related Sec. 2703 are discussed below.

\section{Section 2703 and Section 2704: The Service Attempts to Ignore the FLP}

In 1990, Congress enacted Chapter 14 of the Internal Revenue Code, which includes Sections 2703 and 2704 , to block use of devices such as "estate freezes" which imposed restrictions on the right to sell or use property. Such restrictions, reflected in valuation discounts, reduced the property's FMV for transfer taxes. For example, a parent might enter into a buy-sell agreement for the family business with a child where the agreement contained restrictions on the sale or use of the property. Because a willing buyer would take such restrictions into account in determining the purchase price offered for the business, the impact of the restrictions was to decrease the property's FMV for transfer tax purposes.

\section{Section 2703}

Under Sec. 2703(a), any restrictions imposed on the sale or use of property are ignored when determining its FMV for estate and gift tax purposes. ${ }^{43}$ The only exception to this general rule is Sec. 2703 (b) which permits restrictions to be imposed if they are (1) part of a bona fide business arrangement, (2) are not devices to transfer property to family members for less than FMV and (3) contain terms comparable to those found in arm's length transactions. $^{44}$

The Service has attempted to apply Sec. 2703 in FLP situations, arguing that the FLP itself is as a restriction on the limited partners' rights to sell or use partnership assets and that the relief provisions of Sec. 2703(b) do not apply. This approach subjects the full FMV of the underlying assets, not the reduced FMV of the transferred FLP limited partnership interest, to transfer taxes. In other words, valuation discounts are ignored.

The Tax Court has disagreed. In Strangi, the Court found no support for the Service's interpretation of Sec. 2703(a)(2): "neither the language of the statue nor the language of the regulation supports respondent's interpretation. ${ }^{45}$ The property correctly included in Strangi's estate was his limited partnership interest; not the underlying assets of the FLP. ${ }^{46}$ The Tax Court stated that Congress did not intend Sec. 2703 to treat the partnership properties as assets of the estate where the decedent held only a limited partnership interest at the time of death. ${ }^{47}$

\section{Section 2704}

Section 2704(b) requires that "applicable restrictions" on property be ignored when determining its FMV. This section applies when an interest in a partnership or corporation is transferred and the transferor and her family control the entity immediately before the transfer. ${ }^{48}$ "Applicable restrictions" are those limiting the entity's ability to liquidate which the transferor or any family member, either alone or collectively, can remove. ${ }^{49}$

For example, assume Mother and Son are the only partners in a partnership. The partnership agreement provides the partnership cannot be terminated. Mother dies, leaving her partnership interest to Daughter. As the sole partners, Daughter and Son together could remove the restriction in the agreement on the partnership termination. Under Sec. 2704(b), any valuation discount on the Mother's partnership interest in her estate would be ignored. ${ }^{50}$

The exception to Sec. 2704(b)'s general rule lies in Sec. 2704(b)(3). Here liquidation restrictions are permitted if they are not any more restrictive than existing limits under Federal or state law. ${ }^{51}$ In other words, if Federal or state laws impose equal or greater restrictions on a FLP's ability to liquidate, any similar partnership agreement restriction on liquidation will be respected. Since valuation discounts are employed to reflect such restrictions, if Sec. 2704(b)(3) applies, the discounts should also be upheld. 


\section{Kerr v. Commissioner}

The leading case in the Sec. 2704 area is Baine P. Kerr v. Commissioner, ${ }^{52}$ where the Service raised the Sec. 2704(b) argument against a FLP formed under Texas law. The partnership agreements in Kerr stipulated the entity would dissolve and liquidate upon the earlier of 50 years or agreement of all the partners. ${ }^{53}$ The IRS argued the 50 year clause was more restrictive than applicable Texas law, which permitted a limited partner to withdraw by giving 6 months' notice and thus, transfer taxes should apply to the full FMV transferred. ${ }^{54}$

Disagreeing and ruling for the taxpayer, the Tax Court said the Service erred by looking to state law governing withdrawals, instead of liquidation rights in applying Sec. 2704(b). Relevant Texas law permitted dissolution of the FLP by written consent of all partners, a stipulation echoed in the two Kerr partnership agreements. Thus, Sec. 2704(b)(3) applied, since the liquidation restrictions in the partnership agreements were "no more restrictive than the limitations that generally would apply to the partnerships under Texas law." 55 The Tax Court's decision in Kerr was successfully relied upon by taxpayers in the cases of Knight ${ }^{56}$ and Estate of Jones. ${ }^{57}$ Further, Kerr has just been upheld by the Fifth Circuit Court of Appeals. ${ }^{58}$

In its decision, the Fifth Circuit upheld the $46.4 \%$ effective valuation discounts in $\operatorname{Kerr}$ (17.5\% for minority interest and $35 \%$ for lack of marketability). ${ }^{59}$ However, the appellate court did not follow the Tax Court in examining whether the FLP's restrictions did or did not exceed those found in state law. Rather, the court went back to Sec. 2704(b)'s general rule and focused on whether the liquidation restrictions were invalid because they were removable by the transferor or any family members, acting alone or collectively.

Family members held nearly all of the limited partnership interests in Kerr. However, the taxpayer made a gift of a small interest in the FLP to a university. The IRS argued on appeal that the university would not oppose the family in removing the liquidation restrictions, so Sec. 2704(b) should apply and the valuation discounts should be ignored. The Fifth Circuit disagreed, stating that the Code looked exclusively to family members when determining the removability of restrictions. By having a nonfamily member, the university, hold a limited partnership interest, the family members could not act together to remove the liquidation restrictions. The Court noted that the Code provides "no exception allowing us to disregard non-family members who have stipulated their probable consent to removal of the restriction."

\section{Gift on Formation of FLP}

In order to negate the valuation discounts associated with transfers of FLP interests, the Service may argue under Sec. 2512(b) that the taxpayer has made a gift on the initial formation of the FLP. Sec. 2512(b) provides that where property is transferred for less than adequate and full consideration in money or money's worth, the difference is a gift. The government's leading case is Kincaid, ${ }^{61}$ where the taxpayer transferred ranchland worth $\$ 634,000$ to a family corporation in exchange for nonvoting common and preferred stock valued at $\$ 171,300$. The Fifth Circuit held the difference to be a gift, since the taxpayer could have only had a donative purpose for accepting "patently low-value non-voting stock in exchange for far more valuable ranchland.",62

Where FLPs are concerned, the Service believes the amount of gift on formation equals the difference between the FMV of assets transferred by the taxpayer and the FMV later assigned to the limited partnership interest for transfer tax purposes. Thus, in Strangi, the IRS asserted that a gift of $\$ 3.3$ million was made, representing the difference between the $\$ 9.9$ million in assets contributed to the FLP and the \$6.6 million of value assigned to the limited partnership interest on the estate tax return. ${ }^{63}$ Similarly, in Church, the government argued a gift was made equal to the difference between the $\$ 1.5$ million in assets contributed by the taxpayer to the partnership and the $\$ 617,591$ value of her interest in the partnership at death. ${ }^{64}$

The trial courts in Strangi and Church disagreed with the Service. The partnerships in both cases were pro rata partnerships, in which each investor's interest was proportional to the capital contributed. Because taxpayers' contributions were reflected fully in their partnership capital accounts, the courts found no gift on formation had occurred. Additionally, in Strangi, the Tax Court emphasized no gift had occurred because the decedent did not give 
up control over the assets, since his interest in the FLP exceeded 99\%. ${ }^{65}$ Both Strangi and Church have just been upheld in the Fifth Circuit Court of Appeals for the taxpayer on the issue of gift on formation. ${ }^{66}$

The most critical element in rebutting the IRS' gift on formation argument against a FLP is ensuring that the taxpayer's contributions to the partnership are reflected in the dollar amount of his capital account. This was not the case in Shepard, ${ }^{67}$ where the taxpayer contributed all of the assets, but received only $50 \%$ of the value of the entity. The taxpayer's sons received the other $50 \%$, although they had made no contributions. Here the Tax Court held the taxpayer's transfer represented indirect gifts to his sons. In contrast, in Jones,${ }^{68}$ the court found no gift had occurred on formation of the FLP because "all of the contributions of property were properly reflected in the capital accounts of decedent and the value of the other partners' interests was not enhanced by the contributions of decedent." ${ }^{69}$

The following section examines the Service's use of Sec. 2036 in arguing that the full FMV of assets transferred to a FLP should be included in a decedent's estate and not the lesser value derived after application of valuation discounts. The IRS has enjoyed some success in employing this "retained interest" argument against FLPs. In particular, taxpayers should be aware that the Fifth Circuit has remanded Strangi back to the Tax Court for consideration of the Sec. 2036 issue. ${ }^{70}$

\section{Section 2036}

Sec. 2036(a) "pulls back" previously transferred property into the estate if the decedent retained possession, enjoyment, or income from the property, or where the decedent retained the ability to designate persons having possession or enjoyment rights. Bona fide sales of property do not fall under Sec. 2036. For example, assume a parent gives legal title to her personal residence to a child, but continues to live in the residence as before, without paying rent. Since the parent continues to enjoy the property, the FMV of the house (including any appreciation accrued from the transfer the parent's death) is included in the estate under Sec. 2036.

Retention of stock voting rights is considered a right of enjoyment under Sec. $2036 .^{71}$ If the taxpayer transfers stock in a small corporation to the FLP, the taxpayer should be prepared to reduce his right to vote (directly or indirectly under Sec. 318 ) to less than $20 \%$ of the total combined voting power of all classes of stock. ${ }^{72}$ Alternatively, the taxpayer should consider transferring nonvoting stock to the FLP, if possible.

The Service has enjoyed no small measure of success in applying Sec. 2036 to FLP situations, causing assets purportedly transferred to a FLP during the taxpayer's lifetime (and thus thought removed from estate taxes) to be pulled back into the estate. The reason for the Service's success is simply the taxpayer's blatant disregard for the existence of the FLP. For example, in Estate of Reichardt v. Commissioner, ${ }^{73}$ the taxpayer transferred legal title to substantially all of his property, including his personal residence, to the FLP. ${ }^{74}$ Afterwards, he continued to live in the residence without paying rent. ${ }^{75}$ The decedent also commingled partnership and personal funds--depositing partnership income into a personal account and using the FLP's checking account to pay personal expenses. ${ }^{76}$ The Tax Court sided with the Service and applied Sec. 2036. ${ }^{77}$

Similarly, in Dorothy Schauerhamer ${ }^{78}$ taxpayer's transfers of property to three FLPs were included in her estate when the Tax Court found the decedent had managed the assets and income exactly as she had before the transfer. As in Reichardt, the taxpayer had deposited income from the FLPs into her personal checking account, where it was commingled with income from other sources, ${ }^{79}$ and from which she paid both personal and partnership expenses. ${ }^{80}$

In Strangi, the Service raised the Sec. 2036 issue in a proposed amendment to its original filing with the Tax Court, arguing Sec. 2036 should apply because the taxpayer, acting together with other shareholders of the corporate general managing partner, could cause the FLP to make distributions. Even the majority opinion tacitly agreed with this, noting the actual control exercised by the taxpayer "suggests the possibility of including the property transferred to the partnership in decedent's estate under section 2036." ${ }^{.11}$ Judge Parr's dissenting opinion in Strangi provides examples: the FLP paid for Strangi's nurse's medical expenses, distributed funds to the estate to 
pay estate and inheritance taxes, distributed proceeds to Strangi's children, divided its Merrill Lynch account into four separate accounts for the children, extended lines of credit to the limited partners and advanced funds to the estate to post bonds with the IRS. ${ }^{82}$ "It is clear," the judge noted, that "contrary to the written partnership agreement, decedent and his successor in interest to his partnership interest (decedent's estate) had the ability to withdraw funds at will." $" 83$

The Tax Court did not rule on the Sec. 2036 issue in Strangi, deciding that the Service had not raised the issue in a timely fashion. ${ }^{84}$ However, the Fifth Circuit has just remanded Strangi back to the Tax Court for consideration of this issue. ${ }^{85}$ This is a significant development in the case. If the Tax Court finds that Sec. 2036 applies, as may be expected given the majority's acknowledgement of such a possibility, the assets thought previously transferred to the FLP will be swept back into the estate and the $\$ 3.3$ million valuation discount would disappear.

The sweep of Sec. 2036 may spell future disaster for other FLPs, even those that have successfully challenged the IRS in court. For example, in Knight, the taxpayer and children continued to use a substantial portion of the partnership assets (two houses and a ranch) before and after formation of the FLP. ${ }^{86}$ The children lived in the houses, but did not pay rent to the partnership. Likewise, the taxpayer continued to operate the ranch as before, paying no rent to the FLP until after the Tax Court petition was filed. ${ }^{87}$ Since the taxpayer in Knight was not deceased, Sec. 2036 was not an issue. If the IRS is able to revisit the Knight situation after the taxpayer's death, Sec. 2036 should prove the weapon of choice.

\section{Valuation Discounts}

The application of valuation discounts to FLP limited partnership interests reflects the lack of economic control the limited partner has over the FLP's assets. For example, while a limited partner owns a pro rata amount of the FLP's net assets, he cannot compel distribution of those assets, due to restrictions inherent in the limited partnership format. To reflect this lack of economic control, valuation discounts establish the value of the limited partnership interest as less than the FMV of the pro rata share of assets for transfer tax purposes. Valuation discounts may be claimed to reflect the following restrictions on a limited partnership interest:

- $\quad$ The interest is a minority interest

- $\quad$ The partner cannot easily withdraw from the FLP

- $\quad$ The partner cannot easily transfer his interest

- $\quad$ The partner has no voting rights

- $\quad$ The interest lacks marketability

- $\quad$ The limited partner cannot compel income distributions

The IRS' quarrel with valuation discounts is that they reduce the amount subject to transfer taxes. In Field Service Advice 200049003, the Service first counsels agents to attack the substance of the FLP. Obviously, if there is no FLP, there is no valuation discount. Failing this, the Service recommends arguing that no discount is needed and advances two hypothetical arguments: (1) if a FLP holds passive assets, it is analogous to a trust, where no discount is applied on contribution of assets ${ }^{88}$ or (2) if a FLP holds liquid assets, it is unlikely the transferor would agree to sell such an interest at a discounted value. ${ }^{89}$

However, in advising its agents, the Service has conceded that valuation discounts may be necessary. In FSA 200049003, the Service equated FLPs holding readily marketable assets to publicly traded closed-end mutual funds, and noted the latter trade "at a discount from net asset value of $4 \%$ to $12 \%$...to reflect the disadvantages of a minority interest." ${ }^{90}$ Further, because FLP interests, unlike mutual funds, are not readily marketable, the Service admitted "it may be necessary to concede an additional discount for lack of marketability." 91 FSA 200143004 also agrees that discounts may be necessary for minority interests ${ }^{92}$ and lack of marketability. ${ }^{93}$

In court, once the decision has been made to respect the FLP, the valuation discounts follow. The final amount of the discounts is generally a trade-off between the two sides' respective expert witnesses. Thus, in Stran$g i$, the taxpayer's expert advanced a $33 \%$ effective discount; ${ }^{94}$ the government's, $31 \% .{ }^{95}$ The court used $31 \% .{ }^{96}$ In 
Church, the taxpayer's discount was $42 \%,{ }^{97}$ the government's, zero $;{ }^{98}$ the court used $42 \% .{ }^{99}$ In Knight, the final discount was $24 \%{ }^{100}$ versus the taxpayer's original 44\%. ${ }^{101}$ Taxpayers forming FLPs must recognize that valuation discounts calculated by their expert appraiser will be countered by those determined by the government's expert and plan accordingly.

Valuation discounts exist as a source of controversy for taxpayers and the IRS because of the onerous burden of the transfer taxes. What happens if the transfer tax system is changed? The next section examines recent proposals in Congress to eliminate one of the taxes - the estate tax and discusses the impact of this upon FLPs.

\section{Current Developments - Eliminating The Estate Tax}

In April 2002, the U.S. House of Representatives approved a measure that would have eliminated the estate tax by repealing the sunset provision contained in the 2001 Economic Growth and Tax Relief Reconciliation Act (EGTRRA). PL 107-16). ${ }^{102}$ Although the bill failed to pass the Senate, ${ }^{103}$ the issue enjoyed heavy support and may be raised again in the next fiscal year.

What EGTRRA did in 2001 was slowly drop the transfer tax until 2010, when the rates abruptly plunge to zero. Then, in 2011, the bill restores the tax to its original rate of 55\%. Chart 1 below shows the rate reductions established by EGTRRA. Chart 2 shows the Gift Tax Rate Schedule for years 2002-2011.

\section{Chart 1: Transfer Tax Rates and Unified Credit Amounts}

\begin{tabular}{|c|c|c|}
\hline \multicolumn{2}{|c|}{ Estate and Gift Tax Rates and Unified Credit Exemption Amount } \\
\hline Calendar Year & $\begin{array}{c}\text { Estate and GST Tax Deathtime } \\
\text { Transfer Exemption }\end{array}$ & Highest Estate and Gift Tax Rates \\
\hline 2002 & $\$ 1,000,000$ & $50 \%$ \\
\hline 2003 & $\$ 1,000,000$ & $49 \%$ \\
\hline 2004 & $\$ 1,500,000$ & $48 \%$ \\
\hline 2005 & $\$ 1,500,000$ & $47 \%$ \\
\hline 2006 & $\$ 2,000,000$ & $45 \%$ \\
\hline 2007 & $\$ 2,000,000$ & $45 \%$ \\
\hline 2008 & $\$ 2,000,000$ & $45 \%$ \\
\hline 2009 & $\$ 3,500,000$ & $45 \%$ \\
\hline 2010 & N/A & $0 \%$ Estate Taxes \\
\hline 2011 & $\$ 675,000$ & $35 \%$ Gift Taxes \\
\hline
\end{tabular}

EGTRRA only repeals the estate tax; not the gift tax. It retains the yearly $\$ 11,000$ gift tax exclusion. EGTRRA also limits the step-up in basis for assets passing through the estate, beginning in 2010. A decedent's estate would be permitted to increase the basis of assets transferred by up to a total of $\$ 1.3$ million. The basis of property transferred to a surviving spouse could be increased by an additional $\$ 3$ million, for a total of $\$ 4.3$ million.

\section{Impact of Possible Estate Tax Repeal on FLPs}

If the estate tax is repealed, IRS attacks on transfers of FLP limited partnership interests occurring at death would seem to cease. If there is no tax, there is no need for valuation discounts. The beneficiaries would essentially take a carryover basis for the limited partnership interest transferred, adjusted for the limited step-up of $\$ 1.3$ million mentioned earlier. Ending the estate tax also ends any need for Sec. 2036. Since this section has been a successful tool for the Service's attacks on FLPs, this may be a welcome relief.

Since the gift tax remains in existence under EGTRRA and the 2002 repeal efforts, FLP transfers during the taxpayer's lifetime, such as those in Knight, ${ }^{104}$ Church $^{105}$ and Shepard, ${ }^{106}$ would still be subject to IRS attack for using valuation discounts to reduce exposure to the gift tax. Obviously, one strategy would be to wait until death to 
transfer the assets to the FLP, since there would be no transfer tax at this time. Failing that, the taxpayer must be prepared to continue the battle with the IRS.

Chart 2: Gift Tax Rate Schedule 2002-2011

\begin{tabular}{|c|c|c|c|c|c|c|c|c|c|}
\hline \multirow{2}{*}{\multicolumn{2}{|c|}{ Taxable Estate Bracket }} & \multicolumn{8}{|c|}{ Calendar Year } \\
\hline & & \multirow{2}{*}{2002} & \multirow{2}{*}{2003} & \multirow{2}{*}{2004} & \multirow{2}{*}{2005} & \multirow{2}{*}{2006} & \multirow{2}{*}{$\begin{array}{l}2007- \\
2009\end{array}$} & \multirow{2}{*}{2010} & \multirow{2}{*}{$\begin{array}{l}2011 \text { \& After } \\
\text { (prior law, unless } \\
\text { new law is } \\
\text { reenacted) }\end{array}$} \\
\hline Over & But Not Over & & & & & & & & \\
\hline$\$$ & $\$ 10,000$ & 18 & 18 & 18 & 18 & 18 & 18 & 18 & 18 \\
\hline 10,000 & 20,000 & 20 & 20 & 20 & 20 & 20 & 20 & 20 & 20 \\
\hline 20,000 & 40,000 & 22 & 22 & 22 & 22 & 22 & 22 & 22 & 22 \\
\hline 40,000 & 60,000 & 24 & 24 & 24 & 24 & 24 & 24 & 24 & 24 \\
\hline 60,000 & 80,000 & 26 & 26 & 26 & 26 & 26 & 26 & 26 & 26 \\
\hline 80,000 & 100,000 & 28 & 28 & 28 & 28 & 28 & 28 & 28 & 28 \\
\hline 100,000 & 150,000 & 30 & 30 & 30 & 30 & 30 & 30 & 30 & 30 \\
\hline 150,000 & 250,000 & 32 & 32 & 32 & 32 & 32 & 32 & 32 & 32 \\
\hline 250,000 & 500,000 & 34 & 34 & 34 & 34 & 34 & 34 & 34 & 34 \\
\hline 500,000 & 750,000 & 37 & 37 & 37 & 37 & 37 & 37 & 35 & 37 \\
\hline 750,000 & $1,000,000$ & 39 & 39 & 39 & 39 & 39 & 39 & 35 & 39 \\
\hline $1,000,000$ & $1,250,000$ & 41 & 41 & 41 & 41 & 41 & 41 & 35 & 41 \\
\hline $1,250,000$ & $1,500,000$ & 43 & 43 & 43 & 43 & 43 & 43 & 35 & 43 \\
\hline $1,500,000$ & $2,000,000$ & 45 & 45 & 45 & 45 & 45 & 45 & 35 & 45 \\
\hline $2,000,000$ & $2,500,000$ & 49 & 49 & 48 & 47 & 46 & 45 & 35 & 49 \\
\hline $2,500,000$ & $3,000,000$ & 50 & 49 & 48 & 47 & 46 & 45 & 35 & 53 \\
\hline $3,000,000$ & & 50 & 49 & 48 & 47 & 46 & 45 & 35 & 55 \\
\hline $10,000,000$ & $17,184,000$ & $\mathrm{~N} / \mathrm{A}$ & $\mathrm{N} / \mathrm{A}$ & $\mathrm{N} / \mathrm{A}$ & $\mathrm{N} / \mathrm{A}$ & $\mathrm{N} / \mathrm{A}$ & $\mathrm{N} / \mathrm{A}$ & $\mathrm{N} / \mathrm{A}$ & $5 \%$ surtax \\
\hline
\end{tabular}

Source: CRS adaptation of estate and gift tax rate schedule under prior law.

Notes: The maximum gift tax rate scheduled to be in effect each year is highlighted in bold type. From 2002 to 2009 , the reduction in maximum rate for the gift tax mirrors the estate tax, shown in Table A.1. In 2010, when the estate tax is repealed, the gift tax is retained, but its maximum rate is lowered to $35 \%$. The taxable estate brackets in the leftmost columns identify the level of gifts at which the reduction in the maximum marginal rate will take effect. Even though the cumulative lifetime exemption for taxable gifts is set at $\$ 1$ million from 2002 on, the graduated rates below $\$ 1$ million remain relevant. The exemption still takes effect through a tax credit mechanism. The graduated rates affect the calculation of both the tentative tax liability before the credit and the tax credit.

Source: Congressional Research Service, July 25, 2001 


\section{Tax Planning: Responding to the IRS' Challenges}

\section{The Business Purpose/Economic Substance Challenge}

The courts have diminished the emphasis placed on this argument by the IRS when it comes to FLPs. In general, if a FLP is validly formed under applicable state law, the courts will respect it. Taxpayers should be aware that the courts, in diminishing the business purpose/economic substance test, have now advanced to prominence a "willing buyer/willing seller" standard which asks whether the hypothetical willing buyer would respect the FLP as an entity and adjust the purchase price to reflect the legal restrictions imposed upon a limited partnership interest.

The wise taxpayer will likewise respect the legal form of the FLP to strengthen defenses against IRS attacks. In particular, the taxpayer cannot behave as if the FLP did not exist and hope the courts will agree. At a minimum, the following steps should be adhered to:

- $\quad$ All appropriate actions must be followed to create and recognize the FLP under state law. Legal title to contributed assets must be transferred to the FLP. Appropriate business licenses and permits must be obtained in the FLP's name. When drafting the partnership agreement, care should be taken to ensure that any restrictions on liquidation of the FLP are not more restrictive than applicable state law, to avoid the IRS' application of Sec. 2704.

- $\quad$ The FLP must keep separate business records, have a business checking account and prepare annual reports to partners. Partnership meetings should be held and the minutes recorded. Federal and state partnership income tax returns must be filed.

- $\quad$ Partners must deal at an arm's-length basis with the FLP. Partners should not commingle personal and business funds. If a partner uses a FLP asset, rent equal to an objective FMV should be paid by the partner to the FLP. Taxpayers must recognize that by contributing personal-use assets to a FLP and continuing either to exercise control over the assets or to enjoy the assets' use, they invite attack under Sec. 2036 in estate tax situations.

- $\quad$ Assets must be carefully appraised and documented by an independent appraiser to substantiate valuation discount percentages.

- $\quad$ Gift tax returns must be filed to reflect all assets gifted to children in order to establish the capital balances required to substantiate income distributions in FLPs where partnership capital is a significant factor.

IRS Challenges Under Sec. 2703 and Sec. 2704

\section{Section 2703: Not a Threat to the Taxpayer}

Sections 2703 and 2704 require that restrictions on property be ignored when determining FMV for transfer tax purposes. Sec. 2703 applies to sales and use restrictions on the property and Sec. 2704 to liquidation restrictions.

The Service has attempted to apply Sec. 2703 in FLP situations by arguing that the FLP itself is a restriction on a limited partner's ability to sell or use the partnership property. The courts in Strangi $i^{107}$ and Church $^{108}$ have not agreed with this approach. As with the business purpose test, the judiciary has shown itself unwilling to ignore validly formed FLPs. Sec. 2703 does not seem to pose a problem for FLPs at this point.

\section{Section 2704: Consider Adding a Non-Family Member as Partner}

Taxpayers should be slightly more concerned with the Service's application of Sec. 2704. When a FLP partnership agreement is drafted, it should not contain restrictions on liquidation of a partnership interest that are more restrictive than applicable state law. In Kerr, ${ }^{109}$ the leading case on this issue, the Fifth Circuit has recently 
upheld the Tax Court in its finding that liquidation restrictions in a FLP formed under Texas law did not violate Sec. 2704. The cases of Knight ${ }^{110}$ and Estate of Jones ${ }^{111}$ also successfully relied on Kerr in Tax Court.

Since the Circuit Court's decision in Kerr rested on the court's determination that Sec. 2704(b)'s general rule applied to liquidation restrictions removable only by family members, cautious taxpayers may wish to follow Kerr and transfer a nominal interest in the FLP to a non-family member, such as a college. The addition of a nonfamily member as a limited partner blocks Sec. 2704(b), since family members no longer hold $100 \%$ of the partnership interests and thus will not able to remove liquidation restrictions at will. This was the strategy that upheld Kerr in the Fifth Circuit, where the court ruled Sec. 2704(b) did not apply because the FLP consisted of only family members.

\section{The Gift on Formation Challenge}

The IRS' gift on formation argument, which provides that transferring property for less than its FMV results in a gift and negates any valuation discounts, has had some success in court, most notably in Shepard ${ }^{12}$ and Kincaid. ${ }^{13}$ However, this challenge can be rebutted by the taxpayer transferring property to a FLP by adhering to the fact situations represented in the cases of Strangi ${ }^{114}$, Church $^{115}$ and Jones. ${ }^{116}$ The key is to ensure that the contributing partner's transfers of property are reflected in full in her partnership capital account. Any transfers of limited partnership interests to other family members must occur after (emphasis added) the initial transfer of property and crediting to the capital account, to avoid the unfortunate result in Shepard. ${ }^{117}$

\section{The Sec. 2036 Challenge}

Sec. 2036 has proven to be one of the Service's most successful challenges to FLPs affected by estate taxes. By using Sec. 2036 to pull back property into the estate where the decedent retained incidents of ownership or enjoyment or the ability to assign these rights to others, the IRS in effect voids any valuation discounts on the property.

The Service's success in employing Sec. 2036 is due simply to taxpayer carelessness and disregard for the FLP as a legal entity. Taxpayers in Strangi, ${ }^{118}$ Reichardt, ${ }^{119}$ and Schauerhamer ${ }^{120}$ continued to control and use FLP assets as they had before the FLP's formation. They used FLP funds to pay personal expenses, commingled business and personal monies and lived in FLP-owned residences without paying rent.

The recent Fifth Circuit's decision to remand Strangi back to the Tax Court for consideration of the Sec. 2036 issue will probably result in assets being pulled back into the estate and valuation discounts being lost. Again, this result could easily have been avoided had the taxpayer taken steps to respect the existence of the FLP and dealt with the FLP in an arm's length manner for all transactions.

\section{The Valuation Discounts Challenge}

The courts have not quarreled with the concept of valuation discounts for FLPs. If they recognize the existence of the FLP, the courts permit the discount. However, the courts have shown themselves as willing to accept the discount calculations of the IRS' experts as they have those of the taxpayer's experts. There is no guarantee that the taxpayer's full amount of discount will stand in court. This is not due to any prejudice by the courts against the taxpayer; on the contrary, the Tax Court (and increasingly, the Fifth Circuit), have so far upheld the FLP against IRS challenges. Rather, the final determination of the discount, if decided in court, will often be a compromise between numbers put forth by the two sides' respective expert appraisers.

Because of this negotiated aspect of the valuation discounts, the taxpayer will not generally be able to ensure that his discounts will stand in full and should be prepared to accept a changed discount percentage. The taxpayer may be able to minimize the damage by hiring a qualified independent appraiser with significant successful court experience in this area. 


\section{Conclusions}

Family limited partnerships remain a strong and effective mechanism for transferring family wealth from one generation to another. These entities have proven themselves capable of withstanding IRS audit and court challenges seeking to disregard a FLP's legal existence. The courts have also upheld the use of valuation discounts applied by taxpayers to reduce gift and estate taxes.

In particular, courts have held that a validly formed FLP with liquation provisions paralleling those of applicable state law will withstand Service challenges under the following arguments: economic substance/business purpose, Section 2703 and Section 2704. Countering the IRS' gift on formation argument requires only that the taxpayer's initial transfers to the FLP be reflected in full in his capital account. Avoiding the Service's Section 2036 challenge necessitates that the taxpayer respect the legal form of the FLP and deal with the entity in an arm's-length manner in all transactions. By exercising care in forming and operating the FLP, taxpayers and their advisers can safeguard the transfer of family assets and minimize the tax cost of such transfers.

\section{Endnotes}

1 HR 586 "Fairness for Foster Care Families Bill of 2001" amending the "Economic Growth and Tax Relief Reconciliation Act of 2001.

2 Chart 1 in this paper displays the transfer tax rates and unified credit amounts from 2002 through 2011.

3 Although a majority of the Senate voted to repeal the estate tax (54 to 44), the vote fell short of the 60 vote minimum required to pass budget items.

4 As determined by Sec. 704(e)(3). See HR 1263 and S 936 "Small Business and Financial Institutions Tax Relief Act of 2001", amending Sec. 1361(b)(1)(B). Similar provisions were proposed in 1999.

5 Estate of Charles E. Reichardt, 114 TC 144 (2000).

6 Dorothy Schauerhamer, TC Memo 1997-242, RIA TC Memo I997242, 73 CCH TCM 2855.

7 Solving for $\mathrm{x}$ in the following equation yields $\$ 73,333: \mathrm{x}-.10 \mathrm{x}-[3(\$ 22,000)]$.

$8 \quad(\$ 1,000,000 \times .80) \times .80=\$ 640,000$.

9 Estate of Albert Strangi, 115 TC 478 at 486 (2000), aff'd in part and rem'd in part by Gulig v. Commissioner, 89 AFTR 2d 2002-2977 (CA-5) 6/17/02.

10 Ina F. Knight, 115 TC 506 (2000).

11 Estate of Albert Strangi, 115 TC 478 at 486 (2000), aff'd in part and rem'd in part by Gulig v. Commissioner, 89 AFTR 2d 2002-2977 (CA-5) 6/17/02.

12 IRS National Office Field Service Advice (FSA) 200049003, 12/8/2000.

13 IRS National Office Field Service Advice (FSA) 200143004, 7/5/2001.

14 FSA 200143004 at II59 and I[60; FSA 200049003 at I1110.

15 FSA 200049003 at $\llbracket 105$. See also FSA 200143004 at I58.

16 Rosalie Gulig, Independent Executrix, on behalf of the Estate of Albert Strangi, Deceased, vs. Commissioner of Internal Revenue, 89 AFTR 2d 2002-2977 (CA-5) 6/17/02, (hereinafter referred to as Gulig v. Commissioner), aff'g in part and rem'g in part Estate of Albert Strangi, 115 TC 478 (2000).

17 Baine P. Kerr v. Commissioner, 292 F.3d 490 (CA-5, 2002), 89 AFTR 2d 2002-2838, aff'g Baine P. Kerr v. Commissioner, 113 TC 449 (1999).

18 Gregory v. Helvering, 293 US 465 (1934), 14 AFTR 1191, 35-1 USTC II 9043.

19 FSA 200049003 at $\mathbb{\Phi} 32$.

20 Estate of Albert Strangi, 115 TC 478 at 486 (2000), aff'd in part and rem'd in part by Gulig v. Commissioner, 89 AFTR 2d 2002-2977 (CA-5) 6/17/02.

21 Ina F. Knight, 115 TC 506 at 511 (2000).

22 Estate of Albert Strangi, 115 TC 478 (2000), aff'd in part and rem'd in part by Gulig v. Commissioner, 89 AFTR 2d 2002-2977 (CA-5) 6/17/02.

23 Ina F. Knight, 115 TC 506 at 511 (2000).

24 Judge J. Foley, concurring opinion in Ina F. Knight, 115 TC 506 at 522. (2000).

25 Judge C.J. Wells, concurring opinion in Est. of Albert Strangi, 115 TC 478 at 493 (2000). 
26 Estate of Albert Strangi, 115 TC 478 at 485 (2000), aff'd in part and rem'd in part by Gulig v. Commissioner, 89 AFTR 2d 2002-2977 (CA-5) 6/17/02.

27 Ibid.

28 Ina F. Knight, 115 TC 506 at 511 (2000).

29 Ina F. Knight, 115 TC 506 at 511 (2000).

30 Judge J. Foley, concurring opinion in Ina F. Knight, 115 TC 506 at 522. (2000).

31 Estate of Albert Strangi, 115 TC 478 (2000), aff'd in part and rem'd in part by Gulig v. Commissioner, 89 AFTR 2d 2002-2977 (CA-5) 6/17/02.

32 Ina F. Knight, 115 TC 506 at 511 (2000).

33 Judge J. Foley, concurring opinion in Ina F. Knight, 115 TC 506 at 522. (2000).

34 Estate of Albert Strangi, 115 TC 478 at 486 (2000), aff'd in part and rem'd in part by Gulig v. Commissioner, 89 AFTR 2d 2002-2977 (CA-5) 6/17/02.

35 Ina F. Knight, 115 TC 506 at 513. (2000).

36 Sec. 2502 and 2503.

37 Regs. Sec. 20-2031-1(b) and Sec. 25.2512-1.

38 Ina F. Knight, 115 TC 506 at 514 (2000).

39 Ibid.

40 Estate of Albert Strangi, 115 TC 478 at 487 (2000), aff'd in part and rem'd in part by Gulig v. Commissioner, 89 AFTR 2d 2002-2977 (CA-5) 6/17/02

41 Gulig v. Commissioner, 89 AFTR 2d 2002-2977 (CA-5) 6/17/02, aff'g in part and rem'g in part Estate of Albert Strangi, 115 TC 478 (2000).

${ }^{42}$ Ibid.

43 Sec. 2703(a).

44 Sec. 2703(b)

45 Estate of Albert Strangi, 115 TC 478 at 488 (2000), aff'd in part and rem'd in part by Gulig v. Commissioner, 89 AFTR 2d 2002-2977 (CA-5) 6/17/02.

46 Ibid.

47 Ibid.

48 Sec. 2704(b)(1).

49 Sec. 2704(b)(2).

50 Baine P. Kerr v. Commissioner, 113 TC 449 at 471 (1999), citing H. Conf. Rept. 101-964 at 1137 (199), 1991-2 C.B. 560.

51 Sec. 2704(b)(3)(B).

52 Baine P. Kerr v. Commissioner, 113 TC 449 (1999), aff'd in Baine P. Kerr v. Commissioner, 292 F.3d 490 (CA5, 2002), 89 AFTR 2d 2002-2838.

53 Ibid.

54 Ibid.

55 Ibid.

56 Ina F. Knight, 115 TC 506 (2000).

57 Estate of W.W. Jones II, 116 TC 121 (2001).

58 Baine P. Kerr v. Commissioner, 292 F.3d 490 (CA-5, 2002), 89 AFTR 2d 2002-2838, aff'g Baine P. Kerr v. Commissioner, 113 TC 449 (1999).

59 The valuation discounts are applied sequentially. Here, the discount can be calculated as $17.5 \%+[35 \%$ (1$.175)]=46.4 \%$.

60 Baine P. Kerr v. Commissioner, 292 F.3d 490 (CA-5, 2002), 89 AFTR 2d 2002-2838, aff'g Baine P. Kerr v. Commissioner, 113 TC 449 (1999).

${ }_{61}$ Adaline V. Kincaid, 682 F2d 1220, 50 AFTR 2d 82-6175 (CA-5, 1982), rev'g DC-WD.

${ }^{62}$ Ibid.

63 Estate of Albert Strangi, 115 TC 478 at 489 (2000), aff'd in part and rem'd in part by Gulig v. Commissioner, 89 AFTR 2d 2002-2977 (CA-5) 6/17/02

${ }^{64}$ Elsie J. Church, 85 AFTR 2d 2000-804 (W.D. TX, 2000) 
65 Estate of Albert Strangi, 115 TC 478 at 490 (2000), aff'd in part and rem'd in part by Gulig v. Commissioner, 89 AFTR 2d 2002-2977 (CA-5) 6/17/02

66 Gulig v. Commissioner, 89 AFTR 2d 2002-2977 (CA-5) 6/17/02, Elsie J. Church, 268 F.3d 1063 (CA-5, 2001), 88 AFTR 2d 2001-5352.

67 J.C. Shepherd v. Commissioner, 115 TC 376 at 389 (2000).

${ }^{68}$ Estate of W.W. Jones II, 116 TC 121 (2001).

69 Estate of W.W. Jones II, 116 TC 121 at 128 (2001).

70 Gulig v. Commissioner, 89 AFTR 2d 2002-2977 (CA-5) 6/17/02, aff'g in part and rem'g in part Estate of Albert Strangi, 115 TC 478 (2000).

71 Sec. 2036(b)(1).

72 Sec. 2036(b)(2).

73 Estate of Charles E. Reichardt, 114 TC 144 (2000).

74 Estate of Charles E. Reichardt, 114 TC 144 at 148 (2000).

75 Estate of Charles E. Reichardt, 114 TC 144 at 149 (2000).

76 Estate of Charles E. Reichardt, 114 TC 144 at 152 (2000).

77 Estate of Charles E. Reichardt, 114 TC 144 at 157 (2000).

78 Dorothy Schauerhamer, TC Memo 1997-242, RIA TC Memo I997242, 73 CCH TCM 2855.

79 Dorothy Schauerhamer, TC Memo 1997-242 p. 1505. RIA TC Memo \[97242, 73 CCH TCM 2855.

80 Dorothy Schauerhamer, TC Memo 1997-242 p. 1504. RIA TC Memo đI97242, 73 CCH TCM 2855.

81 Estate of Albert Strangi, 115 TC 478 at 486. (2000), aff'd in part and rem'd in part by Gulig v. Commissioner, 89 AFTR 2d 2002-2977 (CA-5) 6/17/02

82 Estate of Albert Strangi, 115 TC 478 at 495. (2000), aff'd in part and rem'd in part by Gulig v. Commissioner, 89 AFTR 2d 2002-2977 (CA-5) 6/17/02.

83 Ibid.

84 Estate of Albert Strangi, 115 TC 478 at 486. (2000), aff'd in part and rem'd in part by Gulig v. Commissioner, 89 AFTR 2d 2002-2977 (CA-5) 6/17/02.

85 Gulig v. Commissioner, 89 AFTR 2d 2002-2977 (CA-5) 6/17/02, aff'g in part and rem'g in part Estate of Albert Strangi, 115 TC 478 (2000).

86 Ina F. Knight, 115 TC 506 at 511. (2000).

87 Ina F. Knight, 115 TC 506 at 512. (2000).

88 FSA 200049003, \108.

89 FSA 200049003, \1114.

90 FSA 200049003, $\llbracket 110$.

91 FSA 200049003, \[110.

92 FSA 200143004, \$159.

93 FSA 200143004, 160.

94 Estate of Albert Strangi, 115 TC 478 at 483 (2000), aff'd in part and rem'd in part by Gulig v. Commissioner, 89 AFTR 2d 2002-2977 (CA-5) 6/17/02

95 Estate of Albert Strangi, 115 TC 478 at 492 (2000), aff'd in part and rem'd in part by Gulig v. Commissioner, 89 AFTR 2d 2002-2977 (CA-5) 6/17/02.

96 Ibid.

97 Elsie J. Church, 85 AFTR 2d 2000-804 at 2000-808 (W.D. TX, 2000), aff'd in Elsie J. Church, 268 F.3d 1063, 88 AFTR 2d 2001-5352 (CA-5, 2001).

98 Ibid.

99 Ibid.

${ }^{100}$ Ina F. Knight, 115 TC 506 at 519. (2000). The $24 \%$ is calculated by comparing the government's FMV total of $\$ 1,578,060$ to the full FMV of the assets-- $\$ 2,081,323$. The government's nominal discount rate was stated at $15 \%$, but this discount was based on a $\$ 1,800,344$ full FMV for the assets as calculated by the government.

101 Ina F. Knight, 115 TC 506 at 513. (2000).

102 Economic Growth and Tax Relief Reconciliation Act of 2001, PL 107-16.

103 Although a majority of the Senate voted to repeal the estate tax (54 to 44), the vote fell short of the 60 vote minimum required to pass budget items. 
104 Ina F. Knight, 115 TC 506 (2000).

105 Elsie J. Church, 85 AFTR 2d 2000-804 at 2000-808 (W.D. TX, 2000), aff'd in Elsie J. Church, 268 F.3d 1063, 88 AFTR 2d 2001-5352 (CA-5, 2001).

106 J.C. Shepherd v. Commissioner, 115 TC 376 (2000).

107 Estate of Albert Strangi, 115 TC 478 at 483. (2000), upheld on the Sec. 2703 issue in Gulig v. Commissioner, 89 AFTR 2d 2002-2977 (CA-5) 6/17/02.

108 Elsie J. Church, 85 AFTR 2d 2000-804 at 2000-808 (W.D. TX, 2000), aff'd in Elsie J. Church, 268 F.3d 1063, 88 AFTR 2d 2001-5352 (CA-5, 2001).

109 Baine P. Kerr v. Commissioner, 292 F.3d 490 (CA-5, 2002), 89 AFTR 2d 2002-2838, aff'g Baine P. Kerr v. Commissioner, 113 TC 449 (1999).

110 Ina F. Knight, 115 TC 506 at 519. (2000).

111 Estate of W.W. Jones II, 116 TC 121 (2001).

112 J.C. Shepherd v. Commissioner, 115 TC 376 at 389 (2000).

113 Adaline V. Kincaid, 682 F2d 1220, 50 AFTR 2d 82-6175 (CA-5, 1982), rev'g DC-WD.

114 Estate of Albert Strangi, 115 TC 478 at 483 (2000), aff'd in part and rem'd in part by Gulig v. Commissioner, 89 AFTR 2d 2002-2977 (CA-5) 6/17/02.

115 Elsie J. Church, 85 AFTR 2d 2000-804 at 2000-808 (W.D. TX, 2000), aff'd in Elsie J. Church, 268 F.3d 1063, 88 AFTR 2d 2001-5352 (CA-5, 2001).

116 Estate of W.W. Jones II, 116 TC 121 (2001).

117 J.C. Shepherd v. Commissioner, 115 TC 376 (2000).

118 Estate of Albert Strangi, 115 TC 478 at 492 (2000), aff'd in part and rem'd on the Sec. 2036 issue by Gulig v. Commissioner, 89 AFTR 2d 2002-2977 (CA-5) 6/17/02.

119 Estate of Charles E. Reichardt, 114 TC 144 (2000).

120 Dorothy Schauerhamer, TC Memo 1997-242, RIA TC Memo I997242, 73 CCH TCM 2855. 
Notes 